\title{
Varying Indian crustal front in the southern Tibetan Plateau as revealed by magnetotelluric data
}

\author{
Chengliang Xie ${ }^{1,2^{*}} \mathbb{C}$, Sheng Jin ${ }^{1,2}$, Wenbo Wei ${ }^{1,2}$, Gaofeng Ye ${ }^{1,2}$, Letian Zhang ${ }^{1,2}$, Hao Dong ${ }^{1,2}$ and Yaotian Yin ${ }^{1,2}$
}

\begin{abstract}
In the southern Tibetan plateau, which is considered to be the ongoing India-Eurasia continental collision zone, tracing of the Indian crustal front beneath Tibet is still controversial. We conducted deep subsurface electrical modeling in southern Tibet and discuss the geometry of the front of the Indian crust. Three areas along the Yarlung-Zangbo river zone for which previous magnetotelluric (MT) data are available were inverted independently using a three-dimensional MT inversion algorithm ModEM. Electrical horizontal slices at different depths and north-south oriented cross sections at different longitudes were obtained to provide a geoelectrical perspective for deep processes beneath the Tethyan Himalaya and Lhasa terrane. Horizontal slices at depths greater than - $15 \mathrm{~km}$ show that the upper crust is covered with resistive layers. Below a depth of $-20 \mathrm{~km}$, discontinuous conductive distributions are primarily concentrated north of the Yarlung-Zangbo sutures (YZS) and could be imaged from mid- to lower crust. The results show that the maximum depth to which the resistive layers extend is over - $20 \mathrm{~km}$, while the mid- to lower crustal conductive zones extend to depths greater than $-50 \mathrm{~km}$. The results indicate that the conductive region in the mid- to lower crust can be imaged primarily from the YZS to south of the Bangong-Nujiang sutures in western Tibet and to $\sim 31^{\circ} \mathrm{N}$ in eastern Tibet. The northern front of the conductive zones appears as an irregular barrier to the Indian crust from west to east. We suggest that a relatively less conductive subsurface in the northern portion of the barrier indicates a relatively cold and strong crust and that the front of the Indian crust might be halted in the south of the barrier. We suggest that the Indian crustal front varies from west to east and has at least reached: $\sim 33.5^{\circ} \mathrm{N}$ at $\sim 80^{\circ} \mathrm{E}, \sim 31^{\circ} \mathrm{N}$ at $\sim 85^{\circ} \mathrm{E}$, and $\sim 30.5^{\circ} \mathrm{N}$ at $\sim 87^{\circ} \mathrm{E}$ and $\sim 92^{\circ} \mathrm{E}$.
\end{abstract}

Keywords: Indian crust, Southern Tibet, Electrical model, Partial melt

\section{Introduction}

As the largest and most recent orogenic plateau in the world, the Tibetan plateau is becoming one of the focuses of geoscience technique application and a natural laboratory to research global geodynamics and climate change. The Tibetan plateau is generally considered to be a consequence of the ongoing India-Eurasia continental collision since approximately 50-60 Ma (Hu et al. 2015, 2016; Li et al. 2015; Yin and Harrison 2000). The timing of the initial collision has remained controversial, as the results

\footnotetext{
*Correspondence: clx@cugb.edu.cn

1 Key Laboratory of Geo-detection (China University of Geosciences, Beijing), Ministry of Education, Beijing 100083, China

Full list of author information is available at the end of the article
}

have been obtained from different studies such as those based on stratigraphy, paleomagnetism, metamorphism, and magmatism (Hu et al. 2016).

The huge north-south (N-S) shortening with the collision of India and Asia as well as the mechanism of convergence that is expected to be absorbed across the Tibetan plateau (Yin and Harrison 2000) have been widely researched and still remain rather controversial. Three classes of models have been proposed to explain the accommodation of the crustal shortening during the continental collision: the 'rigid block' models, the 'ductile medium' models, and the 'channel flow' models. The plateau crust is described as a rigid medium in the rigid block' models and the lateral extrusion might be along the boundaries for those 'plates' or 'microplates' such 
as the crustal-scale strike-slip faults (Tapponnier et al. 2001). In the ductile medium models, the Tibetan plateau is regarded as a ductile subsurface (England and Houseman 1989), and the crust is thickened as a result of the huge $\mathrm{N}-\mathrm{S}$ shortening, which is expected to be accommodated through a continuous deformation of the lithospheric plate. Recent studies suggest the existence of a 'channel flow' in the mid- to lower crust of the plateau which might explain the varying and complex deformation of the Tibetan plateau (Bai et al. 2010; Clark and Royden 2000).

One of the most significant characteristics of the Tibetan plateau is the thick crust that is twice the thickness of the global average continental crust (Nabelek et al. 2009; Gao et al. 2016; Zhao et al. 2011). Seismic studies show the variation of the Moho depth in both $\mathrm{N}-\mathrm{S}$ and east-west (E-W) directions and the Moho step under the main sutures. Along the $\mathrm{N}-\mathrm{S}$ direction, the Moho depth shows a trend of gradually thinning from the southern part to the northern part beneath Tibet and the maximum thickness $(\sim 75-80 \mathrm{~km})$ is located in the Lhasa terrane along the Yarlung-Zangbo sutures (YZS) (Kind et al. 2002; Xu et al. 2015a; Zhang et al. 2011). In the E-W direction, the western part of the plateau has a thicker crust than the eastern part and the possible Moho step is imaged under the main sutures (Gao et al. 2009).

The Himalaya and Lhasa terranes are considered to be the front area of the continental collision and the possibility of delamination and a 'Moho doublet' with the subduction of the Indian plate is generally agreed upon (Kind et al. 2002; Nabelek and Nabelek 2014; Wittlinger et al. 2009; Zhao et al. 2011). Although evidence for the subduction of the Indian plate appears to be sufficient, the distance of extension of the Indian crust (and/or mantle) is still unclear. As the most effective and practical geophysical methods, seismic imaging (Gao et al. 2013; Karplus et al. 2011; Kind et al. 2002; Nabelek et al. 2009; Nabelek and Nabelek 2014; Xu et al. 2015a, b; Zhang et al. 2011, 2013; Zhao et al. 2011, 2014a, b; Zhao and Nelson 1993) and magnetotelluric (MT) data modeling (Chen et al. 1996; Le Pape et al. 2012; Unsworth et al. 2004, 2005; Wei et al. 2001) have been widely applied to study the deep evolution and tectonic processes of the plateau over the past decades. Results of previous seismological studies have revealed some details for the extension (Chen et al. 2015; Liang et al. 2016; Tian et al. 2015; Xu et al. 2015a; Zhang et al. 2015, 2016, 2011; Zhao et al. 2014b) and we believe that MT data can provide some indirect information to obtain a more comprehensive model. In this paper, we reprocessed previous MT data that were deployed in southern Tibet (Fig. 1) and obtained a three-dimensional (3D) electrical model to study deep structures and processes beneath the collision zone at the crustal scale.

\section{Geologic setting}

\section{Lhasa terrane}

The Lhasa terrane, also called the Gangdese Belt, is bounded by the Bangong-Nujiang sutures (BNS) in the north and the YZS in the south (Fig. 2). The Lhasa terrane, which is considered as an Andean-type active continental margin prior to the initial collision (Mo et al. 2008; Yin and Harrison 2000), contains roughly E-W sedimentary strata and magmatic rocks (Zhao et al. 2009). Prominent magmatism in the Lhasa terrane is represented by widespread collision-related and/or subduction-related porphyry deposits (Hou et al. 2015), post-collisional potassic, and ultrapotassic volcanic rocks (Zhao et al. 2009). The hypothesis of complex remelting and/or crust/ mantle interaction processes is considered the most plausible for the genesis of Jurassic $\mathrm{Cu}-\mathrm{Au}$ and Miocene $\mathrm{Cu}-\mathrm{Mo}$ porphyry deposits in the Lhasa terrane (Hou et al., 2015, 2011; Yang et al. 2016). Meanwhile, ultrapotassic rocks are generally regarded as evidence of mantle delamination (Zhao et al. 2009). Isotopic (Zircon in situ $\mathrm{U}-\mathrm{Pb}$ and $\mathrm{Lu}-\mathrm{Hf}$ ) and geochemical data indicate that the Lhasa terrane has ancient basement rocks up to Archean ages in its center while younger and juvenile crust form both its northern and southern edges ( $\mathrm{Hu}$ et al. 2016; Zhu et al. 2013, 2011).

\section{Himalayan orogen}

The Himalayan orogen is considered as the remnants of the exposed edge of the Indian subcontinent south of the YZS (Fig. 2). Generally, the Himalayan orogen is subdivided into three tectono-stratigraphic units: the Tethyan Himalayan sedimentary sequences (THS), the Greater Himalayan crystalline complex (GHC), and the Lesser Himalayan series (LHS) (Hou et al. 2012; Hu et al. 2016; Yin and Harrison 2000). The THS is bounded by the YZS in the north and the north-dipping south Tibetan detachment (STD) in the south. The northern zone of the THS is dominated by Mesozoic to Paleocene outer shelf, while the southern part includes platform carbonates and diverse terrigenous units of Paleozoic to Eocene age $(\mathrm{Hu}$ et al. 2016). A prominent structure is the roughly E-W trending north Himalayan gneiss domes that are considered as the collision-related type. The gneiss domes generally indicate the exhumation of the mid- to lower crust. The core of the gneiss domes is normally dominant granitoid plutons (with weak or no magmatic fabrics) and high-grade metamorphic rocks. The margin appears as granitic gneisses showing magmatic fabrics, while the mantle shows high-grade schists and gneisses from the lower crust (Ding et al. 2016b; Xu and Ma 2015). The GHC and LHS are structurally defined by the STD and the Main Central Thrust (MCT) from top to bottom. The Neoarchean to early Paleozoic amphibolite to granulite 
facies gneisses, amphibolites, granulites, and widely intruded early to middle Miocene leucogranites are detected in the GHC (Streule et al. 2010; Xu et al. 2013).

\section{Yarlung-Zangbo suture zone}

The nearly E-W trending YZS zone extends for more than $2000 \mathrm{~km}$ and is generally regarded as the boundary that separates the Gondwana affinities to the south from those that belong to Eurasia in the north $(\mathrm{Xu}$ et al. 2015b). The most important feature is the discontinuous belt of ophiolites that is considered as remnants of the Jurassic-Cretaceous Neotethyan oceanic lithosphere. The YZS is bounded by the south-dipping Great Counter Thrust to the north and the north Himalaya volcanosedimentary formations to the south (Liu et al. 2012; Yin 2006). The discontinuous and fault-bounded ophiolite massifs along the YZS are underlain by mélanges that contain deep marine sedimentary and high-grade metamorphic rocks as well as ophiolitic materials (Guilmette et al. 2008; Xu et al. 2015b). Recent studies have discovered diamonds and a wide range of unusual deep mantle minerals from the Luobusa ophiolite along the YZS (Yang et al. 2015). Different from the diamonds found in kimberlites and subduction-related ultrahigh-pressure metamorphic rocks, these diamonds represent a completely new mode of occurrence of diamonds on Earth (Xu et al. 2015b; Yang et al. 2015).

\section{Data and methods Acquisition and processing}

The MT field acquisition was conducted over the past 20 years since 1995 . In this study, MT data from several $\mathrm{N}-\mathrm{S}$-oriented and E-W-oriented profiles, which were sponsored by the Chinese Geological Survey, Chinese National Natural Science Foundation, and especially the International Deep Profiling of Tibet and Himalaya (INDEPTH), were collected. A total of 163 stations were included in this study. Among them, 126 stations were deployed with broadband MT data (BBMT) and 37 stations were deployed with BBMT as well as long period MT data (LMT) (Fig. 1). For these 37 stations, BBMT and LMT data were merged. The data were divided into three areas, namely A, B, and C. The basic MT data information in each area is as follows (Fig. 1): (1) A, 26 BBMT stations from $\mathrm{N}-\mathrm{S}$-oriented northwest Himalaya profile that run along $\sim 80^{\circ} \mathrm{E}$ and were deployed in 2006. Nine BBMT stations trend roughly in E-W direction and were deployed in 2007. (2) B, 20 BBMT stations from line800 (Gyirong-Cogen profile) and 23 sites from line-900 (Tingri-Comai profile) that were deployed in 2001 and

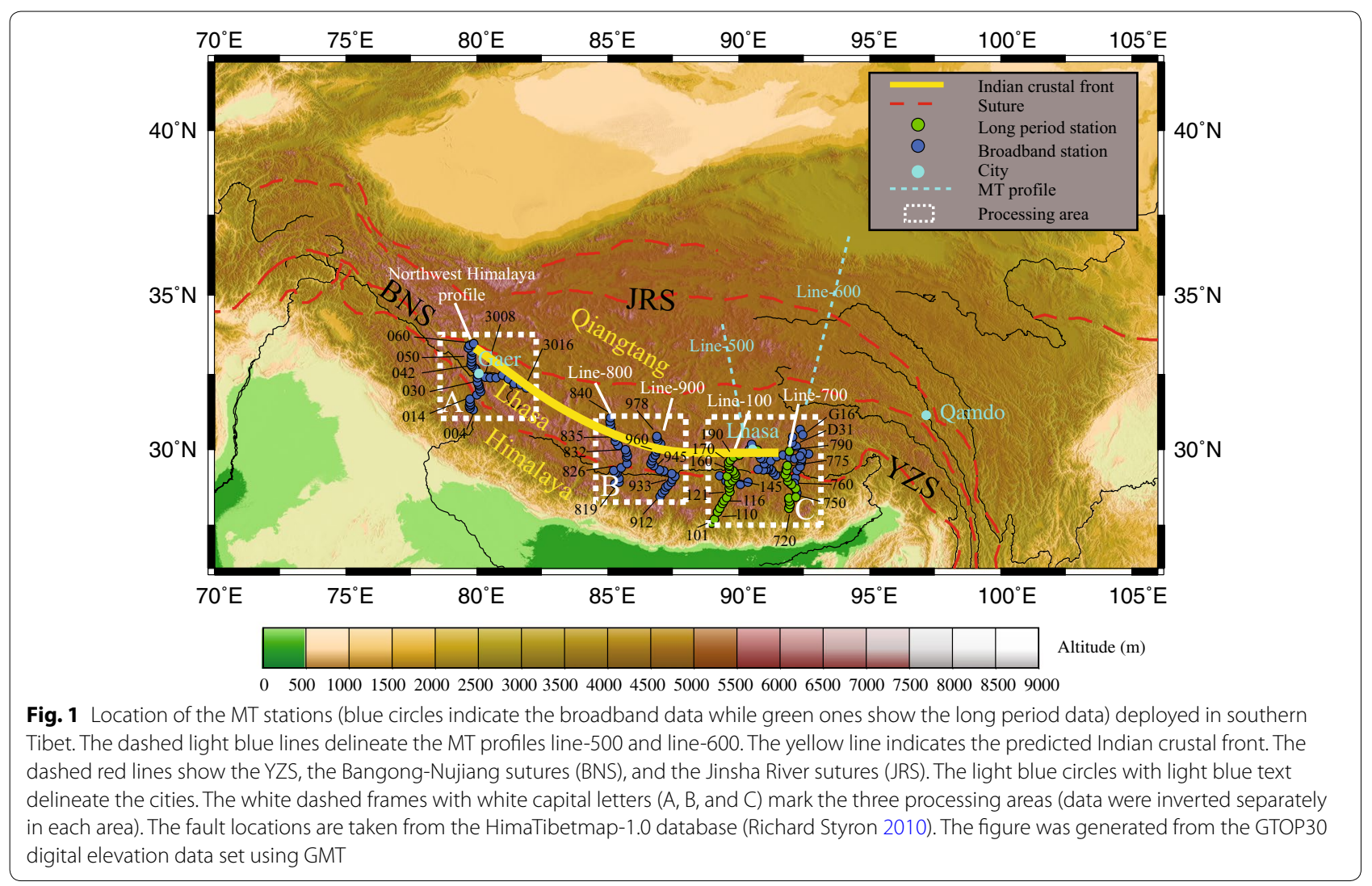


2004 , respectively. Both lines are directed roughly $\mathrm{N}-\mathrm{S}$ and line-800 runs along $\sim 85^{\circ} \mathrm{E}$ while line- 900 is along $\sim 87^{\circ}$ E. (3) C, 17 BBMT from Yangbajain-Zhanang profile conducted in 2013, 24 stations with BBMT and LMT from line-100 (Yadong-Xuegula), which was finished in 1995, 11 BBMT from line-2000 (Lhaze-Markam) and 13 BBMT from Lhunze-Nyainrong profile deployed in 2004 and 2012, respectively, and 20 BBMT with 13 LMT from line-700 conducted in 2001. Most profiles included in area $\mathrm{C}$ trend roughly $\mathrm{N}-\mathrm{S}$ except line-2000, which approximately runs along E-W. The USA EMI MT-24NS, LIMS, and Phoenix MTU-5 instruments were employed in the field to record five channels of MT data (Ex, Ey, $\mathrm{Hx}, \mathrm{Hy}$, and $\mathrm{Hz}$ ). The transfer functions of all the stations were obtained using a robust algorithm, and some of them were optimized using the remote reference method. The frequency band of the final MT sounding data was $320 \mathrm{~Hz}$ to $2000 \mathrm{~s}$ for BBMT and $100 \mathrm{~Hz}$ to $10,000 \mathrm{~s}$ for LMT.

\section{Three-dimensional (3D) inversion}

In this study, we employed a 3D MT inversion algorithm ModEM utilizing the nonlinear conjugate gradient (NLCG) optimizing method (Egbert and Kelbert 2012; Kelbert et al. 2014). It is one of the most popular 3D MT inversion methods to obtain the subsurface electrical structures beneath the study areas. 3D modeling was conducted independently for the different areas (A, B, and
C). The starting models were uniform $100 \Omega \mathrm{m}$ half space with cells as follows: (1) A, $72 \times 67 \times 48$ (72 in the N-S direction, 67 in the E-W direction, and 48 in the vertical direction) for 35 sites. (2) B, $84 \times 72 \times 48$ for 43 sites. (3) C, $88 \times 91 \times 48$ for 85 sites. We used the full impedance (all four complex components) for six periods in each order of magnitude, logarithmically spaced between 0.01 and $2000 \mathrm{~s}$ for areas A, B and $0.01-3000 \mathrm{~s}$ for area C. In the 0.01-1000 s band, there were five orders of magnitude representing 30 periods. On the other hand, the number of periods in the last order of magnitude (between $1000 \mathrm{~s}$ to maximum period) depended on the maximum period for the data. Therefore, we used more than 30 periods for inversion in each station. We set the error floor at $10 \%$ of $\left|Z_{\mathrm{xy}}{ }^{*} Z_{\mathrm{yx}}\right|^{0.5}$ for the diagonal elements and at $5 \%$ of the same modulus for the anti-diagonal elements. The final normalized root-mean-square (r.m.s.) misfit of the modeling was 1.04 after 61 iterations for area A, 1.18 after 82 iterations for area $\mathrm{B}$, and 1.39 after 111 iterations for area C. The 3D inversions were conducted independently for the three areas and a discrete subsurface resistivity model with 3D grid was obtained for each area. Using an interpolation method, we merged the three inversion results together and obtained the final continuous electrical model that is shown in Figs. 6 and 7. It is important to note that the subsurface model beneath the areas with no data might be inaccurate. The distribution of the site by site r.m.s. misfit is shown in Fig. 3; small r.m.s. values are

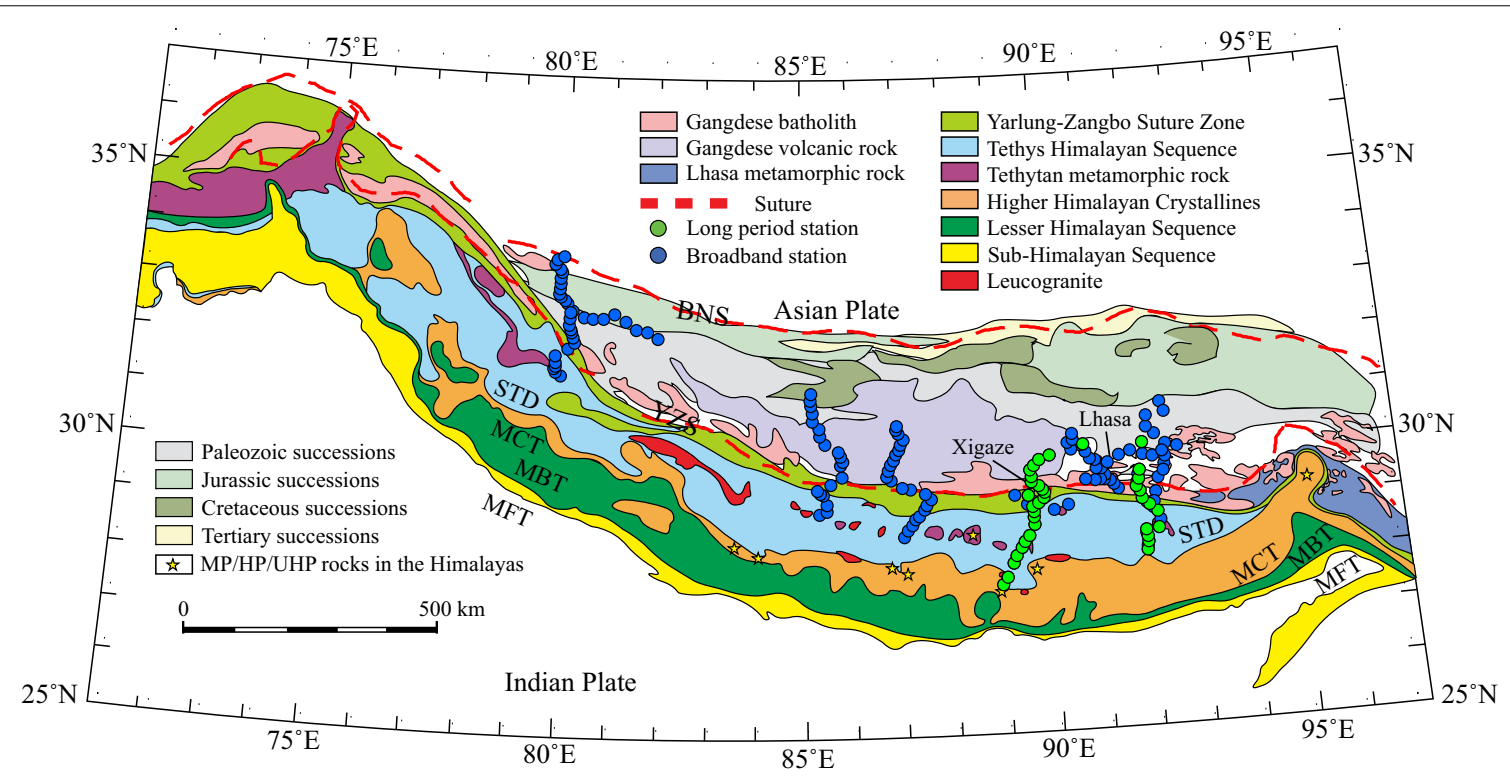

Fig. 2 Simplified geologic map of the study area (modified after Ding et al. 2016a; Hu et al. 2016; Yin and Harrison 2000). The blue circles indicate the broadband data while green ones show the long period data. The dashed red lines show the sutures, YZS and BNS. South Tibetan detachment (STD), Main Central Thrust (MCT), Main Boundary Thrust (MBT), Main Frontal Thrust (MFT), Medium-pressure (MP), High-pressure (HP), and Ultrahighpressure (UHP) 
shown in green, whereas larger values are shown in red. The stations have an r.m.s. $<2$ which indicates a good fit except for 15 stations $(835,924,927$, and 930 in area B, 2038, 2044, 750, 755, 775, 790, D16, 769, 771, 140, and 175 in area $\mathrm{C})$. The apparent resistivity and phase horizontal pseudo-slices of observed data and response data for off-diagonal impedance elements are illustrated in Figs. 4 and 5. The interpolation method was also used to combine the observed and response data from the stations to obtain horizontal pseudo-slices. For illustration purposes, one typical period in each order of magnitude was selected to be presented in Figs. 4 and 5. It should be noted that the comparisons of results for other periods indicate a similar situation. The comparison between observed and response data in Figs. 4 and 5 shows that they are in good agreement before a few $100 \mathrm{~s}$, although several stations have differences in the impedance phase. The apparent resistivity is well fitted also for the long period data while the impedance phase appears to be inconsistent.

The main thing to stress here is that the areas outside the MT profiles might be imaged with artificial anomalies because of limitations in data. Thus, the following discussion and interpretation should be mainly specified for the areas along and/or close to the MT profiles.

The results suggest that the resistivity layers above $-10 \mathrm{~km}$ are distributed from south to north within all three study areas, whereas small and sporadic conductors could be imaged primarily in the area $C$ (Fig. 6a-d). Areas with punctate distribution of conductors are consistent with the collision-related deposit zone such as porphyry deposits in the Gangdese magmatic belt (Hou et al. 2015; Yang et al. 2016), the chromite deposits along the YZS (Xu et al. 2012, 2015b; Yang et al. 2015), and the prospect deposit belt along the gneiss domes in the Tethys Himalayan domain (Ding et al. 2016b; Hou et al. 2012; Xu et al. 2012). The resistivity cover extends over $-20 \mathrm{~km}$ in the vertical direction and had a central resistivity of more than $1000 \Omega \mathrm{m}$ (Figs. 6 and 7). Remarkably, the roughly $\mathrm{N}-\mathrm{S}$-oriented resistivity 'barriers' were imaged even in the mid- to lower crustal slices in east Tibet. However, the resistivity bodies in the western part gradually shrank and eventually disappeared under $-25 \mathrm{~km}$. The subsurface medium beneath $-25 \mathrm{~km}$ was imaged as large scale but discontinuous conductive zones (Fig. 7). Conductive zones had a central resistivity less than $10 \Omega \mathrm{m}$ and crossed the YZS from the Lhasa terrane to Himalayan above $-40 \mathrm{~km}$ but were primarily concentrated in the northern part of the YZS below $-40 \mathrm{~km}$.

\section{Resolution tests}

As MT data are generally more sensitive to the top depth of conductors, the vertical extension depth of the imaging conductors of the inversion model needed to be further constrained. We replaced the conductors with resistive blocks at different depths and the resistive blocks were set from the top depth to the last layer of the models. We conducted 3D forward modeling to check for an obvious increase in r.m.s. at some top depths of resistive blocks. The sharp increase in r.m.s. indicates that the models are sensitive to the replaced conductors. Additionally, the corresponding top depth of resistive blocks should be the lowest boundary of the conductive layers. We set both 1000 and $100 \Omega \mathrm{m}$ resistivity bodies with different top depths instead of the conductive layers and calculated the r.m.s. ('local' r.m.s.) from only the sites located in the rebuilt resistivity zones (the conductive layers in the model). The results of the resolution tests are shown in Fig. 8. It is worth noting that the 'local' r.m.s. here is different from the overall r.m.s. mentioned above. We could test the presence and extension depth of the conductors by checking whether there was an obvious increase in 'local' r.m.s. The results of $1000 \Omega \mathrm{m}$ resistivity bodies indicate a sharper increase in the 'local' r.m.s. (Fig. 8b$1, \mathrm{c}-1, \mathrm{~d}-1$ ); however, similar results are also presented in Fig. 8b-2, c-2 and d-2 for $100 \Omega$ m resistivity blocks. The results indicate an 'r.m.s. step' above $-45 \mathrm{~km}$, and we suggest that the confidence interval of the downward extension depth of conductive layers is from 45 to $-35 \mathrm{~km}$ beneath southern Tibet. This indicates that the reliable maximum extension depth is from -35 to $-45 \mathrm{~km}$. The results indicate that there is low resolution beneath $-50 \mathrm{~km}$ because of the limited data period.

\section{Comparison with previous models}

The same data set was used by previous MT studies that have achieved remarkable success. Since 1995, MT has become one of the most important approaches to reveal deep structures and processes under the plateau. The prominent and discontinuous mid- to lower crustal conductors were imaged in all $\mathrm{N}-\mathrm{S}$-oriented MT profiles (Unsworth et al. 2005; Wei et al. 2009). Moreover, the resistive covers that extended over $-20 \mathrm{~km}$ were imaged in the Gangdese terrane. The previous two-dimensional (2D) models suggest significant amounts of fluids, probably due to a combination of aqueous fluids overlying a layer of partial melting (Unsworth et al. 2005; Wei et al. 2009).

There are both similarities and differences between the previous works and recent findings from this work. The northwest Himalayan profile (Fig. 1) indicates a conductive layer between the depths from approximately -20 to approximately $-40 \mathrm{~km}$, and an increase in the thickness from south to north (Unsworth et al. 2005). The cross section along $\sim 79.9^{\circ} \mathrm{E}$, Fig. 9a, shows a similar conductive layer that is mainly concentrated in the northern 


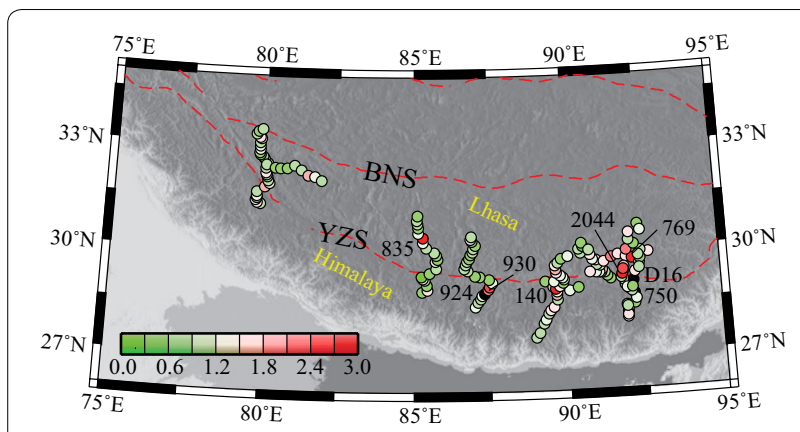

Fig. 3 The site by site r.m.s. misfit distribution in the study area after final iteration using ModEM. The circles delineate the MT stations whereas the filled color shows the value of the r.m.s. The dashed red lines show sutures, YZS and BNS

part (C1). Meanwhile, the resistive cover extends to approximately $-20 \mathrm{~km}$ for both $2 \mathrm{D}$ and $3 \mathrm{D}$ models. In the south of YZS, the upper crustal layer appears to be more resistive in the 3D model (Figs. 6 and 9). The 2D model of line-800 (Fig. 1) is in good agreement with 3D model and the results suggest a two-layer structure in the northern portion of the YZS (Unsworth et al. 2005). The southern end of line- 800 is imaged as high resistivity in the 2D model, while it is relatively low resistivity in the 3D results. The results of the 2D (Wei et al. 2009) and $3 \mathrm{D}$ (along $\sim 86.8^{\circ} \mathrm{E}$, Fig. 9b-900) models are almost consistent for line-900 (Fig. 1). The main difference is the resistive cover and more details imaged in the $2 \mathrm{D}$ results. Unlike the above profiles, there are notable differences between the previous works and our new model for line100 (Fig. 1). The 2D model (Unsworth et al. 2005; Wei et al. 2001) indicates a huge highly conductive mid- to lower crust and the conductors extend to approximately over $-60 \mathrm{~km}$. However, horizontal slices (Figs. 6 and 7) and cross sections (along $\sim 89.5^{\circ} \mathrm{E}$, Fig. 9c-100) suggest a relatively poorly conductive subsurface model. The structure of the main anomaly appears to be similar but the resistivity value is different. Compared to the $2 \mathrm{D}$ result of line-700 (Fig. 1), the imaged mid- to lower crustal conductors have relatively high resistivity in the $3 \mathrm{D}$ model. It should be noted that some new broadband MT data were included in the 3D inversion for area C.

In previous studies, the data were inverted with a $2 \mathrm{D}$ NLCG algorithm of Rodi and Mackie (2001). The MT forward studies suggest that the transverse magnetic (TM) mode would be a preferred choice for 2D inversion of field data (Cai and Chen 2010). Additionally, the previous studies also suggest that the transverse electric (TE) mode data can be more sensitive to near surface 3D effects (Ledo et al. 2002; Unsworth et al. 2004; Wannamaker et al. 1984). Therefore, previous studies mainly used 2D inversion algorithm and the TM mode (and/or the vertical magnetic field) transfer functions. We conducted the new 3D inversion with full impedance data in this work. On the other hand, 2D MT profiles were inverted with 3D inversion and interpolation method was used to get the final continuous model. For 2D inversions, stations deviating from profile were projected on the lines that were perpendicular to regional strike. Thus, the differences between the previous 2D models and the cross-sectional maps (Fig. 9) of new 3D models are probably due to the impact of missing data. Also, it should be noted that this study has data limitations. Meanwhile, more fine meshes were used in the previous 2D studies and resulted in more details in the upper crust of 2D models. In contrast, much smoother structures were imaged in the 3D model. The above reasons probably account for differences between the previous results and the new models.

\section{The Indian crustal front}

Previous seismological studies (Kosarev et al. 1999; Nabelek et al. 2009; Owens and Zandt 1997; Zhang et al. 2011; Zhao et al. 2014b) have indicated that the Indian crust continues to underthrust or be subducted beneath southern Tibet at least over the Himalayan and up to the south Lhasa block, but there has been some controversy regarding the northern limit and geometry of the Indian crust. One cause of the uncertainty is the complicated subsurface structures and the possible 'bright spots' (or/ and conductive layers) might play a key role in affecting the resolution of seismic imaging. Early deep seismic reflection profiling shows the first results of the crustal structures beneath the collisional region and marks the Main Himalayan Thrust (MHT). However, the north end of the profile is located in the Tethyan Himalaya (Zhao and Nelson 1993). Receiver function data along the INDEPTH profiles roughly across the whole plateau in NNE-SSW direction indicate that the Tibetan-Himalayan system is composed of northward underthrusting Indian lithosphere, the separate thin Tibetan lithosphere, and the southward underthrusting Asian lithosphere. The Indian lower crust appears to be limited in the south of BNS as inferred from the so-called 'Moho doublet' (Zhao et al. 2011). According to Owens and Zandt (1997), the Indian crust along $92^{\circ}-93^{\circ} \mathrm{E}$ thins by up to $20 \mathrm{~km}$ from south to north in southern Tibet and underthrusts to the BNS. They also suggest that the crust of the northern plateau is partially melted. Kosarev et al. (1999) suggest a detached Indian lithospheric mantle beneath Tibet, however, they do not discuss the details of the northern end of the Indian crust. The tomography of the Array Network of Tibetan International Lithospheric Observation and Probe Experiment project in western Tibet shows that the Indian plate is sub-horizontal and 


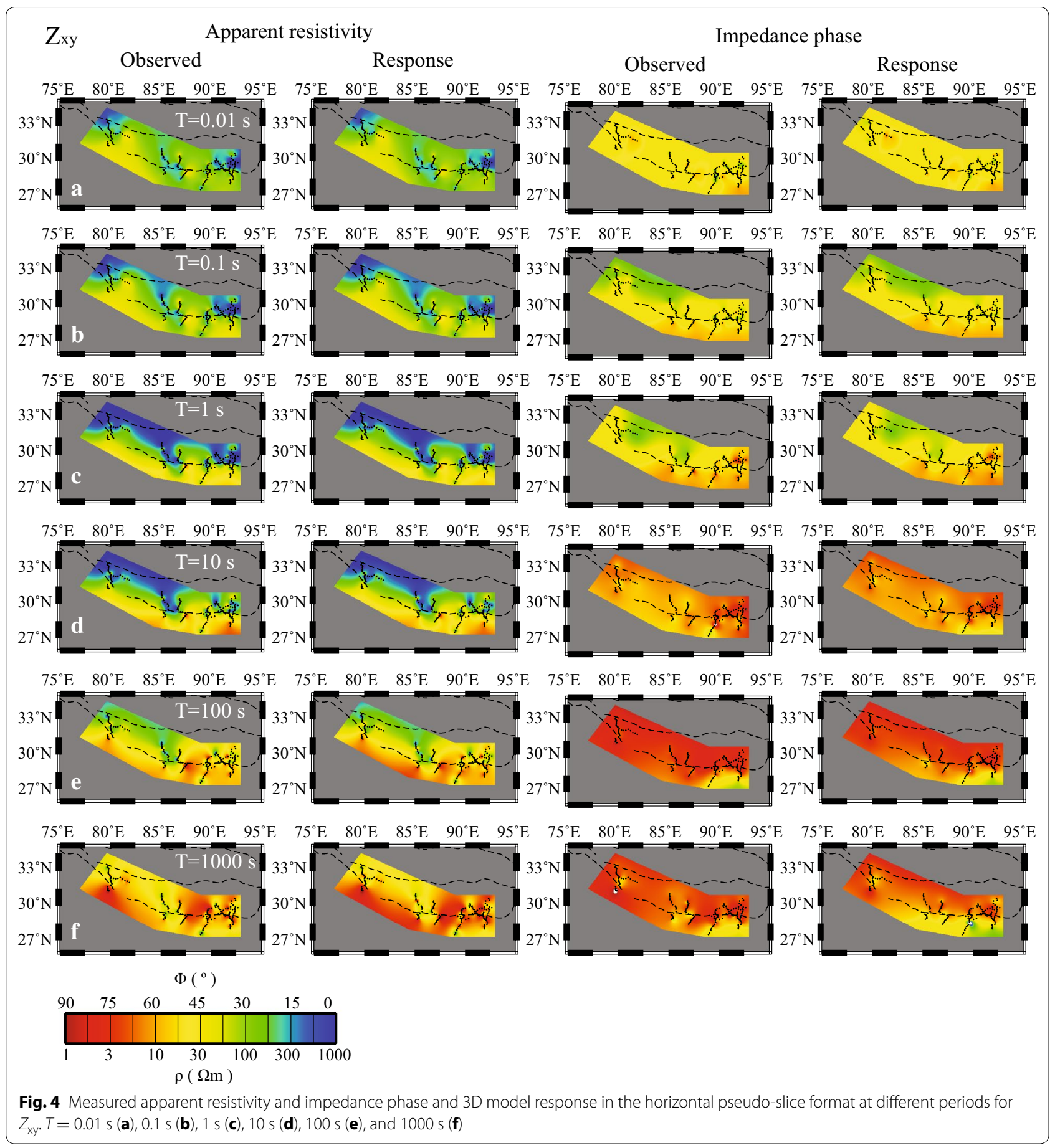

underthrusting even to the Jinsha River suture (JRS). However, it still seems difficult to trace the Indian crust (Zhao et al. 2014b). Zhang et al. (2011) summarize the previous seismic studies in the Tibetan plateau and suggest the diversity of the leading edge of the subducted Indian lithosphere. From an E-W trending seismic array (TIBET-31N), Chen et al. (2015) suggest a slab tearing and/or break-off model of Indian lithosphere with different subduction angles. The results show that the Indian lithospheric slab reaches farther north in the west because of the lesser dip angle. Using teleseismic bodywave data from the same profile (TIBET-31N), Liang et al. (2016) suggest the asthenosphere upwelling through gaps in the Indian lithosphere and lateral flows above the 


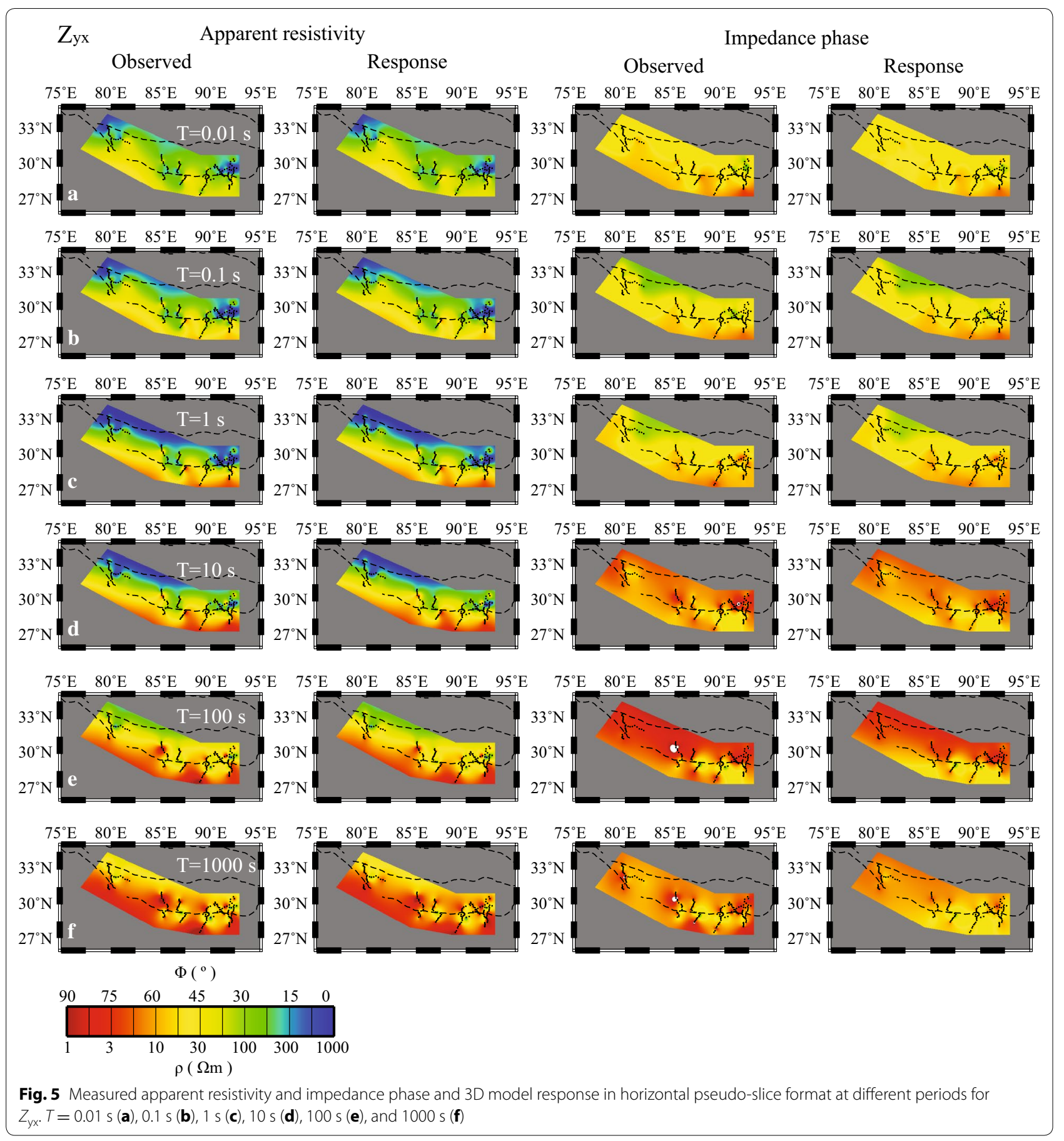

subducting slab. It is worth noting that the results from TIBET-31N lack resolution within the crust and only subduction of the Indian mantle lithosphere with delamination is suggested. The results also suggest a weak middle crust and weakly coupled relation between the crust and the lower lithosphere (Tian et al. 2015). Studies of metamorphism suggest an opposite model where the northeastern margin of the Indian continent was shallowly subducted beneath southern Tibet, while the west part has a greater subduction angle (Ding et al. 2016a, b). Geochemical and isotopic data delineate a subduction model where the Indian plate reached only as far northward as the BNS zone and then plunged into the mantle. This explanation is from the evidence that isotopic 

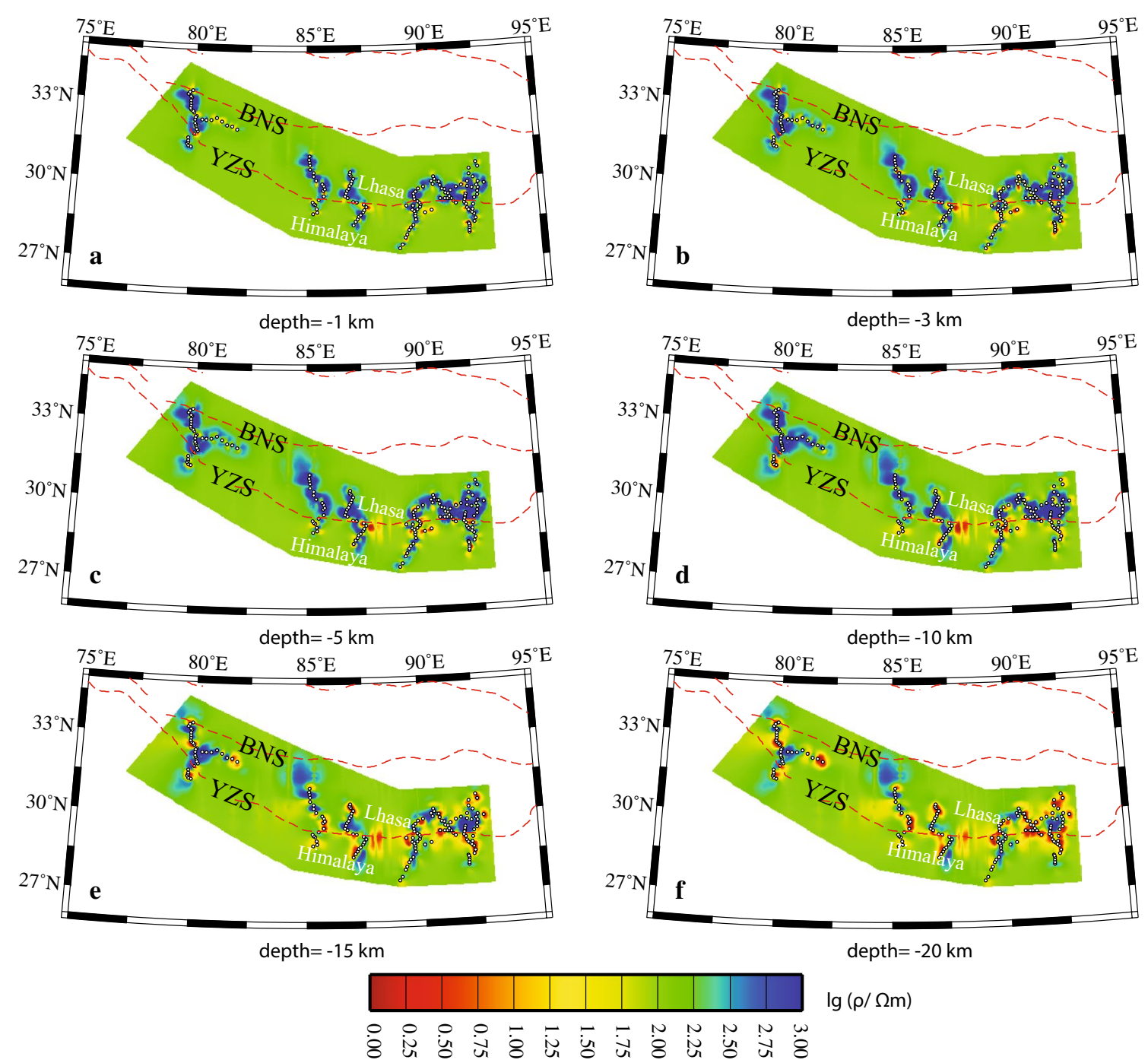

Fig. 6 Horizontal slices of the electrical model from -1 to $-20 \mathrm{~km}$. The dashed red lines show sutures, YZS and BNS. Areas of low resistivity are shown in red while the high resistivity are shown in blue. Panels $\mathbf{a}$ to $\mathbf{f}$ are for depths from -1 to $-20 \mathrm{~km}$

characteristics of volcanic rocks in the northern Tibet have not been influenced by the Indian continental materials (Zhao et al. 2009).

The studies mentioned above are more inclined to provide constraints for the lower Indian continental lithosphere but less detail is available for the crustal features beneath southern Tibet. From a roughly N-S-oriented seismic array in western Tibet, Nabelek et al. (2009) suggest that the Indian crust could be traced to $31^{\circ} \mathrm{N}$. Receiver function image indicates that the lower Indian crust is eclogitized and a significant middle crustal lowvelocity zone (LVZ) is imaged along the MHT (Nabelek et al. 2009). Recently, a new seismic reflection profile across the western Himalayas along $\sim 81.5^{\circ} \mathrm{E}$ was finished and a crustal-scale duplexing model is believed to be the accommodation for the collision beneath the YZS (Gao et al. 2016). Meanwhile, the authors demonstrate (Gao et al. 2016) the accretion of Indian crust into the overlying orogenic wedge, while only a small proportion of the Indian crust (less than $\sim 15 \mathrm{~km}$ thick) is underthrust further north. Although the debate of the impact of different models on crustal processes and features and/or northern limit of Indian crust is still difficult to value, a weaker mid- to lower crust beneath southern Tibet is considered due to the imaging of LVZ and/or high conductors along the MHT. Moreover, it appears to be plausible to regard these weak zones as evidence to trace the north underthrust Indian lower crust.

Figure 9 delineates the cross-sectional maps from the $3 \mathrm{D}$ subsurface geoelectrical model along different 

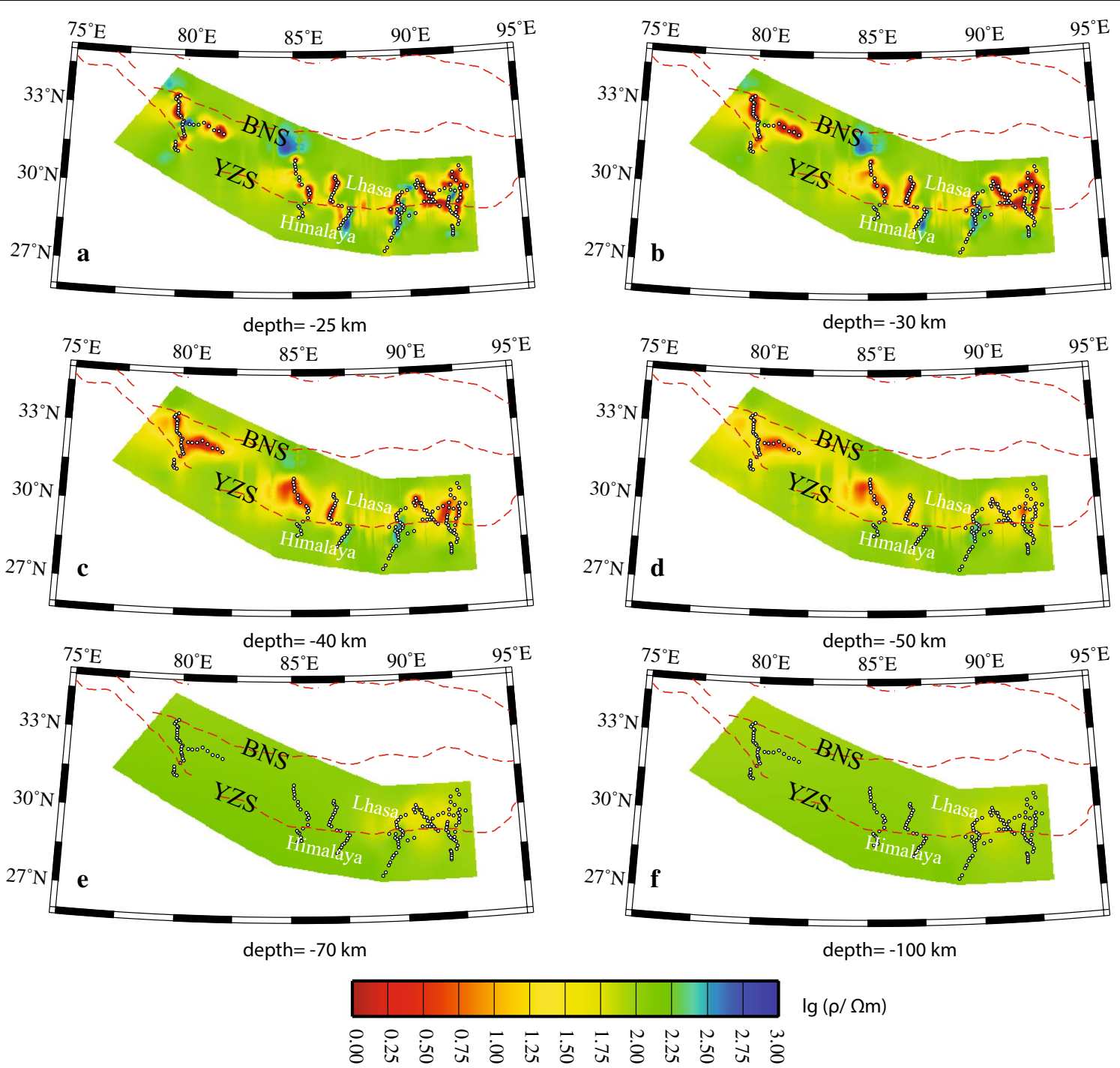

Fig. 7 Horizontal slices of the electrical model from -25 to $-100 \mathrm{~km}$. The dashed red lines show sutures, YZS and BNS. Areas of low resistivity are shown in red while the high resistivity areas are shown in blue. Panels $\mathbf{a}$ to $\mathbf{f}$ are for depths from -25 to $-100 \mathrm{~km}$

longitudes in southern Tibet. The resistive layers ( $\mathrm{R} 1$ to R5) are imaged above $\sim 20 \mathrm{~km}$ and suggest at cold and strong Lhasa block overlying the Indian plate. Also, the resistive covers probably reflect the extensive and strong magmatic events beneath the plateau and the shallow covers might be the reflection of granite and volcanic materials of the Lhasa terrane. The results show large scale mid- to lower conductive zones imaged in southern Tibet. Additionally, the middle crust conductive layers cross the YZS from the Tethyan Himalaya to Lhasa block in the eastern part, while they were mainly imaged in the Lhasa block in the western part (Figs. 6, 7, and 9). This is consistent with the previous 2D inversions (Wei et al. 2009) of the same profiles. However, we notice that the conductors beneath $-30 \mathrm{~km}$ are primarily imaged north of YZS from west to east areas in southern Tibet.

The previous studies indicate that MT impedance data are more sensitive to the integrated conductivity (total conductance) rather than the individual thickness and conductivities (Unsworth et al. 2004). Also, the crustal rheology studies with MT data suggest that the bulk resistivity is less well determined (Rippe and Unsworth 2010)and thus, it is more reliable to calculate the conductance of a particular crustal layer. Figure 10 shows conductance of the cross sections (in Fig. 9) along different longitudes in southern Tibet. The black circles delineate the conductance of the depth from -20 to $-45 \mathrm{~km}$ and the black crosses indicate conductances of the depths 


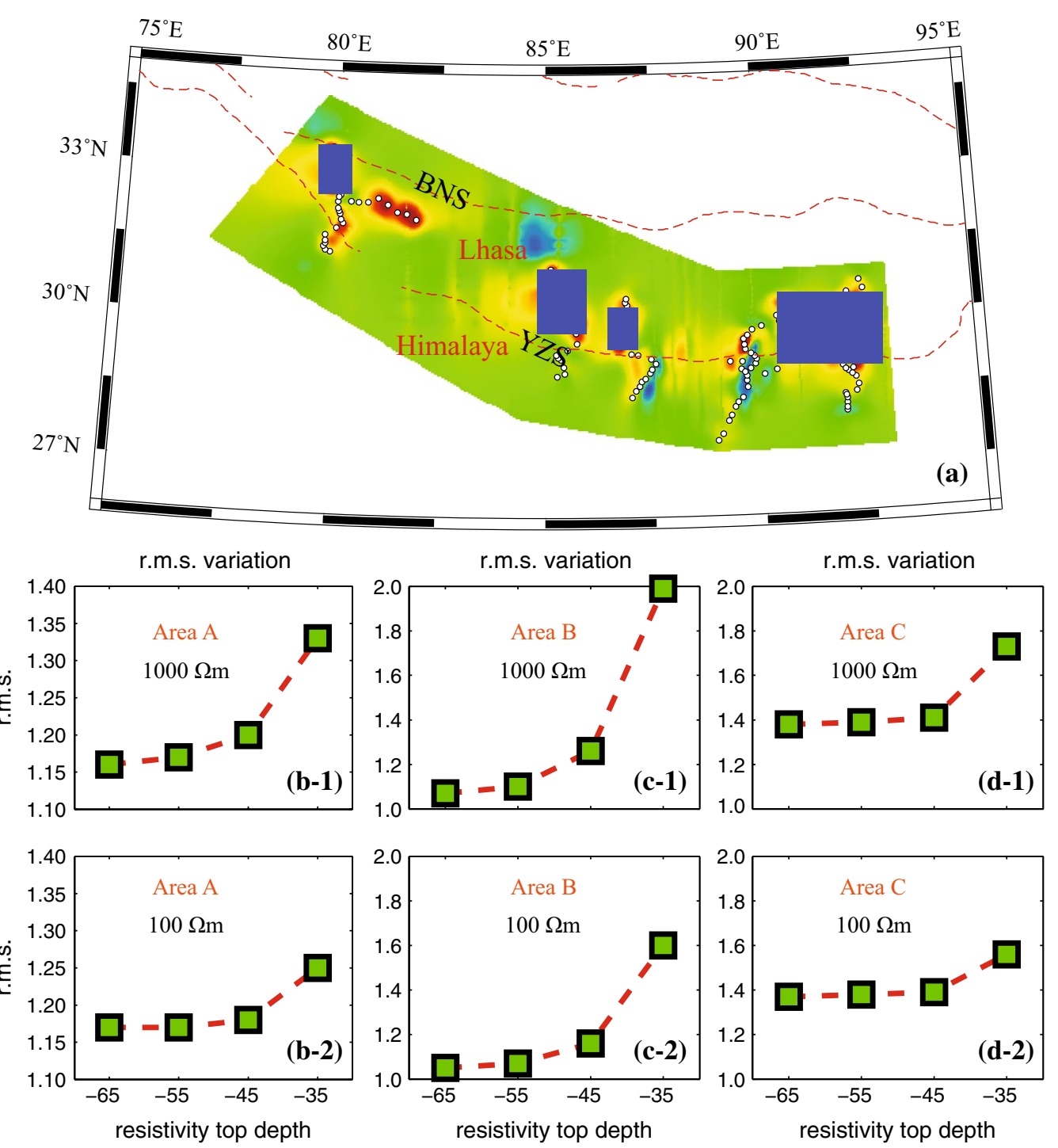

Fig. 8 Resolution tests for the downward extension depths of conductive zones in the 3D model. a The blue blocks mark the resistivity bodies that are set with different top depths. The dashed red lines show the YZS and BNS. b-d The r.m.s. misfit variation with the different top depths of resistivity bodies of the area A, B, and C, respectively. b-1, c-1, d-1 Indicate the results from $1000 \Omega$ m resistive blocks while (b-2, c-2, d-2) from $100 \Omega \mathrm{m}$ resistive blocks. The r.m.s. is calculated only from the sites located in the blue blocks. The 3D forward modeling is performed for areas $A, B$, and C independently

from 0 to $-45 \mathrm{~km}$. The results show that the two conductances roughly coincide in the area north of the YZS. We suggest that the conductors are mainly concentrated at the depth from -20 to $-45 \mathrm{~km}$ because of the little contribution to conductance from depth 0 to $-20 \mathrm{~km}$. This is consistent with the resistive layers imaged in the cross sections (Fig. 9). The approximate equal values of the two conductances are reasonable to a certain extent because conductance is not sensitive to the resistive bodies. The huge conductive layers in our model result in a large value of conductance. Additionally, compared to the conductance itself, the difference between the two conductances is relatively small (Fig. 10). On the other hand, there are differences between the two conductances in the southern part which implies that the upper crust of the south part is relatively more conductive than the north part. Also, we noticed some 'outliers' on the different lines: stations $821-824$ on line B-800, stations $115-117,130-135$ on line $\mathrm{C}-100$, and stations $720-735$ on line C-700 (Fig. 10). Meanwhile, the cross sections (Fig. 9) indicate that the shallow mediums are imaged as conductive bodies beneath the above stations. Thus, 


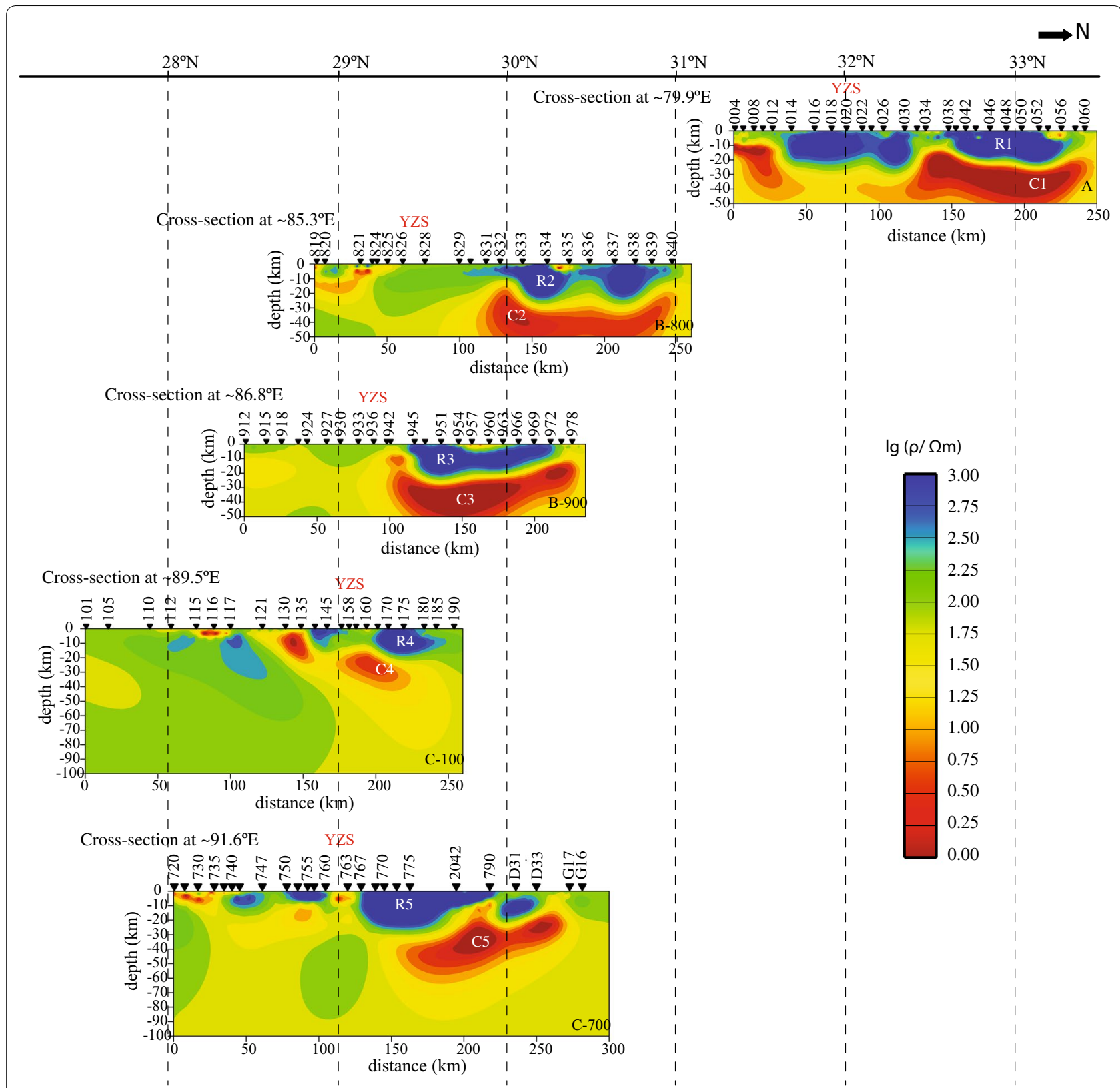

Fig. 9 Resistivity cross-sectional maps along different longitudes in southern Tibet. R1 to R5 are the imaged resistivity bodies, whereas C1 to C5 are the conductors

we suggest the 'outliers' (large conductance) are caused by those shallow conductors in the southern part. The conductance of the mid- to lower crust north of the YZS corresponds to a bulk resistivity of 1-8 $\Omega \mathrm{m}$. Using Archie's Law, previous studies suggest that a bulk resistivity of $10 \Omega \mathrm{m}$ require a melt fraction of $4-9 \%$, while $3 \Omega \mathrm{m}$ requires a melt fraction of $10-23 \%$ (Le Pape et al. 2015; Rippe and Unsworth 2010). Meanwhile, the laboratory measurements suggest that a melt fraction of $5-10 \%$ reduces the crustal strength by one order of magnitude under partially melting conditions (Rippe and Unsworth 2010; Rosenberg and Handy 2005). We suggest that the highly conductive subsurface materials and the corresponding melt fractions indicate weak mid- to lower crust beneath the southern Lhasa block. We believe that these weak zones are consistent with the LVZ along the MHT from previous seismic studies and could be the evidence to trace the northern limit of the Indian crust. Because of the northern extension distance of the MT profiles, we realize that the northern end of our model is 
limited. Thus, the Indian crust might have reached further north than the MT profiles suggest. Considering the inflexion of reduction of the conductance, we suggest the north underthrust and/or subducted Indian crust has at least reached at $\sim 33.5^{\circ} \mathrm{N}$ along $\sim 80^{\circ} \mathrm{E}, \sim 31^{\circ} \mathrm{N}$ along $\sim 85^{\circ} \mathrm{E}$, and $\sim 30.5^{\circ} \mathrm{N}$ along $\sim 87^{\circ} \mathrm{E}$ and $\sim 92^{\circ} \mathrm{E}$, and the northern Indian crustal front is imaged as irregular geometry structures (Fig. 11).

The previous MT profiles for line-500 (Wei et al. 2001) and line-600 (Unsworth et al. 2004) were deployed in the north of line-100 and line-700, respectively (Fig. 1). The 2D inversion results (Unsworth et al. 2004; Wei et al. 2001) indicate that a huge scale of conductors is also imaged in mid- to lower crust beneath the north Tibet, however, the conductors are not continuous in the N-S direction beneath the Tibet. Meanwhile, the 2D models of line-500 and line-600 suggest that the southern Qiangtang terrane has relatively higher resistivity than the northern Lhasa terrane (Unsworth et al. 2004, 2005; Wei et al. 2001). Therefore, we infer that the low resistivity and/or LVZ along the MHT probably halted in the south of the BNS. It is likely that the Indian crust has not reached as far as the Qiangtang terrane.

\section{Discussion}

A number of previous studies suggest the partial melting beneath the southern Lhasa block due to the mid to lower low-velocity and/or low-resistivity zones from seismic and/or MT data. Seismic studies in western Tibet indicate that low-velocity zones exist widely in the middle crust and high velocity anomalies are imaged in the lower crust beneath southern Tibet and the hypothesis of radiogenic heating source appears to be unreasonable (Zhang et al. 2016). Zhang et al. (2015) suggest a LVZ above the northward underthrusting Indian slab beneath the YZS due to melts and/or fluids associated with the dehydration of the Indian plate. Unsworth et al. (2005) discuss the crustal rheology beneath the Himalaya and southern Tibet by establishing a relationship between MT data and the partial melt fraction to obtain the effective viscosity. The model was optimized by Rippe and Unsworth (2010) and the velocity of channel flow could be calculated from the conductance of layer under specific assumptions. They suggest a conductance exceeding 10,000 $\mathrm{s}$ at midcrustal depths in the southern Lhasa block and that the corresponding effective viscosities are in agreement with a viscosity of the order $10^{19}$ Pas that is required to sustain the crustal flow (Rippe and Unsworth 2010).

Besides geophysics data, Eocene adakitic rocks in the Lhasa block are also interpreted as products from partial melting of an eclogitic source from the lower crust (Wang et al. 2014). The gneiss domes spread in the northern Himalayan domain indicate thermal-tectonic processes (magmatism and/or migmatization) and possible partial melting in the mid- to lower crust (Xu and Ma 2015). Geochronological and geochemical data for dioritic dykes in the southern Gangdese magmatic belt suggest that the magma source is dominated by partial melting of lithospheric mantle and is then subsequently contaminated by crustal material during ascent (Ma et al. 2016). However, it is notable that xenocrysts in the dykes indicate a deep process with a heterogeneous source in the middle Eocene (41 Ma) and it appears difficult to determine the present deep thermal structure. Geochemical data from Jiru $\mathrm{Cu}$ deposit located in the Gangdese porphyry $\mathrm{Cu}$ belt suggest that the post-collisional Miocene porphyry intrusions were generated by partial melting of the subduction-modified lower crust (Yang et al. 2016). Also, the results indicate increasing of water content over $4 \mathrm{wt} . \%$ with fractional crystallization (Yang et al. 2016) that would actively enhance the conductance and corresponding partial melting (Le Pape et al. 2015). Studies of porphyry $\mathrm{Cu}$ deposits also suggest that potassic magmas are probably related with partial melting of the thickened juvenile mafic lower crust or delaminated lower crust (Hou et al. 2011). Also, one of the prominent factors for the metallogenesis is the release of the high water content on the breakdown of amphibole in eclogite and garnet amphibolite during melting. On the other hand, the increase in the $\mathrm{H}_{2} \mathrm{O}$ content would induce partial melting that is reflected as low velocity and resistivity.

To explain the origin of the thin, seismic LVZ along the MHT revealed by Hi-CLIMB project (Nabelek et al. 2009), Nabelek and Nabelek (2014) presented thermokinematic calculations and metamorphic $\mathrm{P}-\mathrm{T}-\mathrm{t}$ paths of the Indian lower crust. The results showed that the LVZ along the inclined portion of the MHT indicates that the wet melting was induced by dehydration of the Indian lower crust, while the LVZ above the Indian lower crust was best explained by dehydration melting due to strain heating (Nabelek and Nabelek 2014). Our results support partial melting along the MHT and in mid- to lower crust beneath the Lhasa block. Dehydration associated with the mineralization in the orogenic belt appears to enhance partial melting. Meanwhile, models that include free fluids overlying partial melt in mid- to lower crust beneath southern Tibet could not be ruled out from our results.

It is suggested that the southern Tibetan detachment system (STDS) is related to southward exhumation from the underthrust and/or subducted Indian upper crust. One of the mechanisms attempts that explain formation of the STDS is 'channel flow' or extrusion of the orogenic wedge (Wang et al. 2014). The Hi-CLIMB seismic results could not indicate unequivocal evidence for active channel flow because of the thin LVZ but thinning of the 


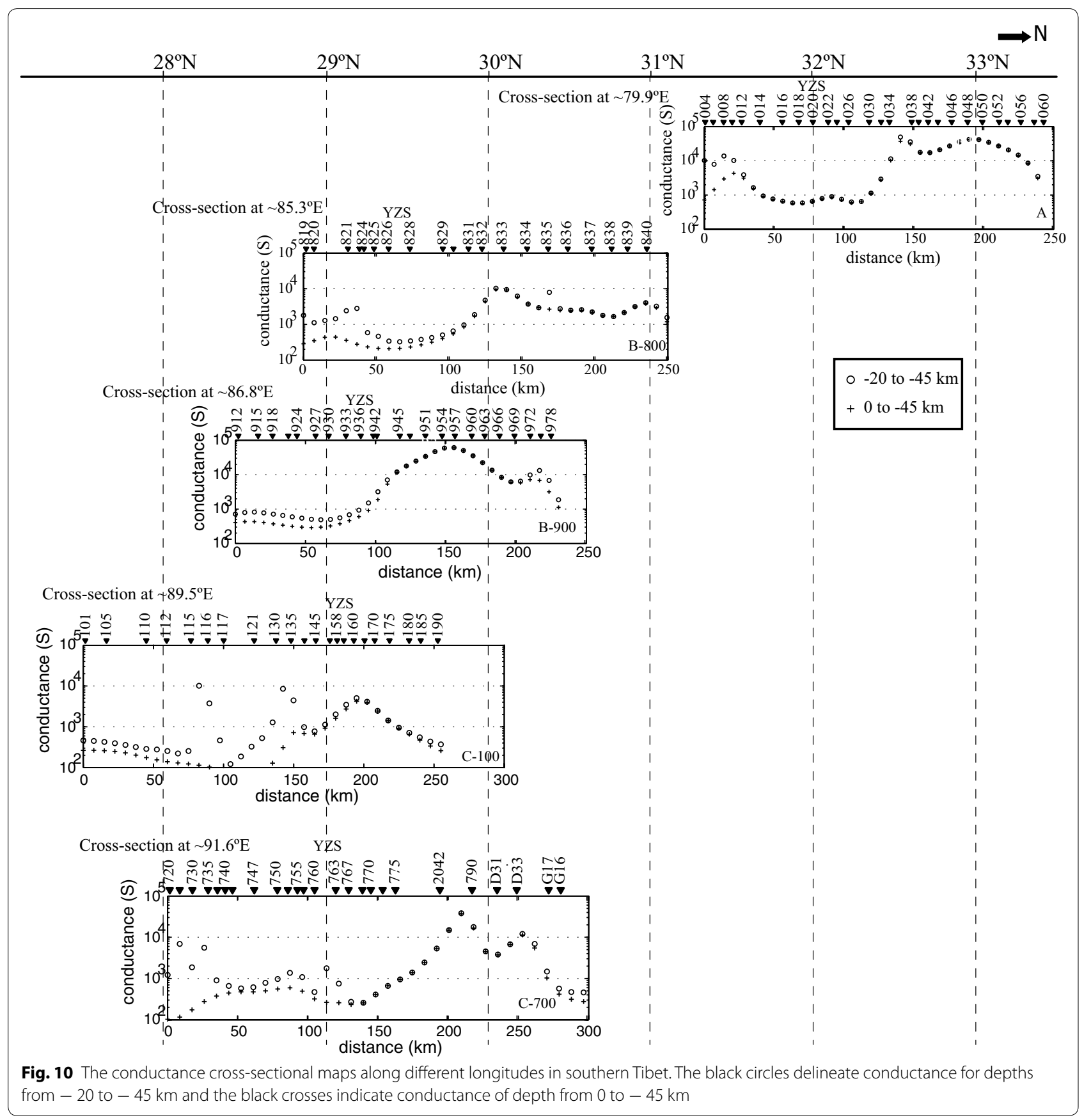

Indian crust beneath Lhasa block appears to indicate the migration of the Indian upper crust along the MHT which acts as a conduit for crustal transfer (Nabelek et al. 2009; Nabelek and Nabelek 2014). A recent seismic study prefers the model 'thrust duplexing' than 'channel flow' to explain the removal of the upper, possibly more felsic and weaker, underthrusting crust and the subsequent transfer into the overlying plate (Gao et al. 2016). Our resistivity models show that conductive layers cross the
YZS in the eastern part and are primarily imaged in the Lhasa block in the western part. Meanwhile, the conductive layers crossing the YZS are mainly concentrated in the middle crust (depth approximately above $-30 \mathrm{~km}$ ). Thus, our resistivity models could not fully provide the evidence for active channel flow because the conductive layers that were interpreted as partial melting appear to be too thin to allow vigorous flow. This is consistent with another seismic study (Nabelek et al. 2009). However, 


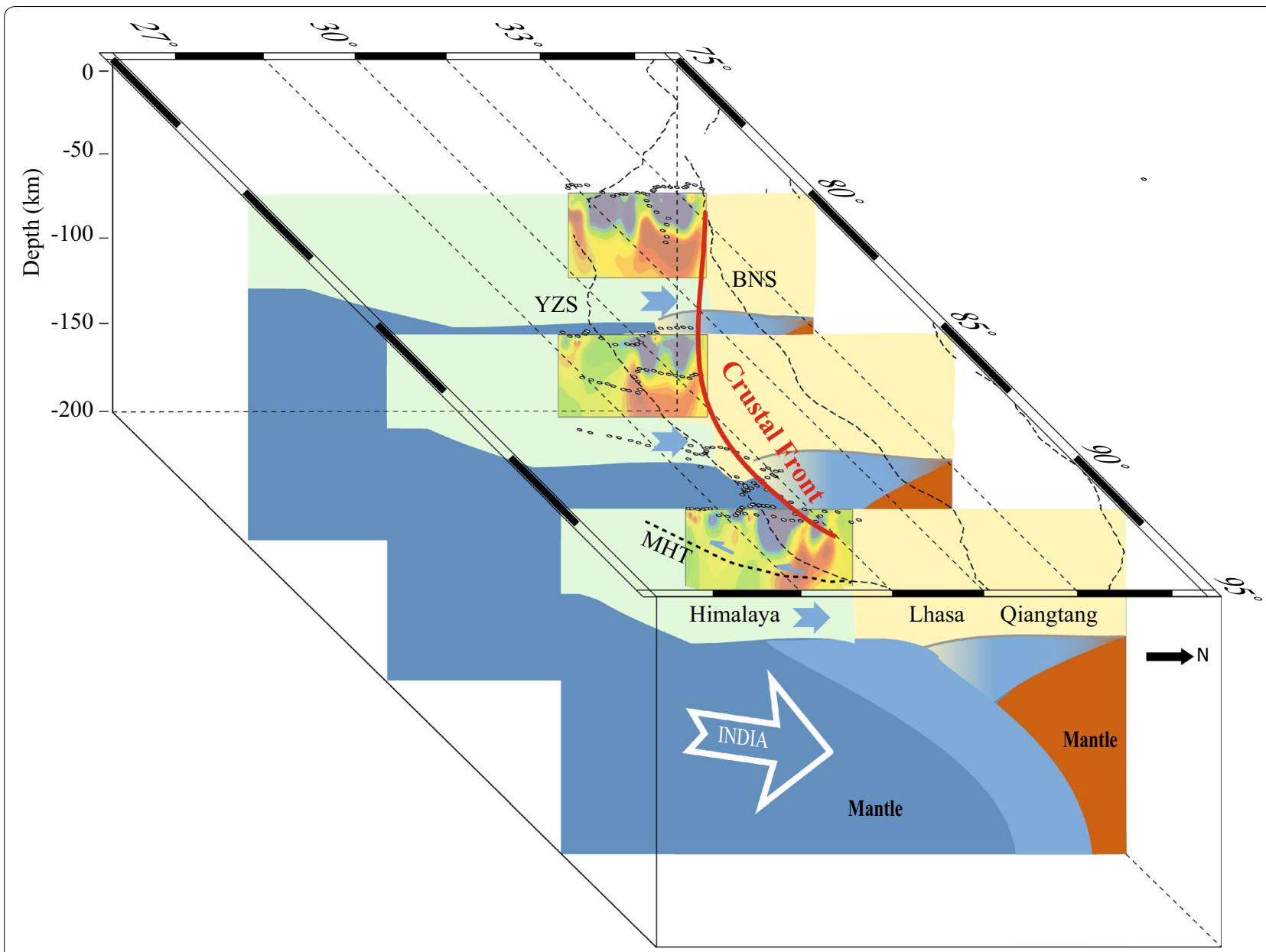

Fig. 11 Cartoon interpretation of the varying Indian crustal front beneath southern Tibet (modified after Nabelek et al. 2009). The red line indicates the predicted Indian crustal front. The sutures are delineated with dashed black lines. The Indian lower crust reaches farther north in the west part. The hypothetical extrusion southwards from Tibet (blue arrows) acts as a conduit which transfers the upper to middle Indian crust into Himalaya in the east part

the depth of the interpreted ductile zones is still debated between the resistivity and velocity models. We suggest that the southwards extrusion in the middle crust transfers the underthrust Indian upper to middle crust into the Himalayan orogenic wedge in the east part of the study area. Additionally, this improves the results of our previous study (Xie et al. 2016) which was limited by the data period.

\section{Conclusions}

We obtained a 3D geoelectrical model using previous MT profiles in southern Tibet with ModEM algorithm. The mid- to lower crust is imaged as conductive layers which were interpreted as ductile zones with partial melting enhanced by plates' motion and/or dehydration. We suggest that conductive layers above the lower Indian crust could provide evidence to trace the underthrust Indian crust. The results show that the Indian crustal front is varies from west to east beneath the southern Tibet and the Indian crust reaches further north in the west (Fig. 11).

The middle crustal conductive layers cross the YZS in eastern Tibet and were primarily imaged in the Lhasa block in western Tibet. We suggest that the crossing thin conductive layer could be interpreted as a possible southwards extrusion that transferred the Indian upper to middle crust into the Himalayan orogenic wedge. This explanation is supported by the seismic results that only the Indian lower crust is imaged beneath southern Tibet.

\section{Abbreviations}

MT: magnetotelluric; YZS: the Yarlung-Zangbo sutures; BNS: the BangongNujiang sutures; JRS: the Jinsha River sutures; N-S: north-south direction; E-W: east-west direction; THS: Tethyan Himalayan sedimentary sequences; GHC: Greater Himalayan crystalline complex; LHS: Lesser Himalayan series; INDEPTH: International Deep Profiling of Tibet and Himalaya; BBMT: broadband MT data; LMT: long period MT data; 3D: three dimensional; STD: south Tibetan 
detachment; STDS: southern Tibetan detachment system; MCT: Main Central Thrust; MBT: Main Boundary Thrust; MFT: Main Frontal Thrust; MP: Mediumpressure; HP: High-pressure; UHP: Ultrahigh-pressure; 2D: two-dimensional; NLCG: nonlinear conjugate gradient; TM: transverse magnetic; TE: transverse electric; MHT: Main Himalayan Thrust; LVZ: low-velocity zone.

\section{Authors' contributions}

CX carried out the magnetotelluric modeling, participated in the data acquisition and model interpretation, and drafted the manuscript. SJ, WW, and GY participated in the data acquisition and analyses. LZ, HD, and YY participated in the data acquisition and processing. All authors read and approved the final manuscript.

\section{Author details}

${ }^{1}$ Key Laboratory of Geo-detection (China University of Geosciences, Beijing), Ministry of Education, Beijing 100083, China. ${ }^{2}$ School of Geophysics and Information Technology, China University of Geosciences (Beijing), Beijing 100083, China.

\section{Acknowledgements}

This study was funded by the National Natural Science Foundation of China (41404059), the National High Technology Research and Development Program ('863'Program) of China (2014AA06A603), and the Open Fund (GDL1502) of Key Laboratory of Geo-detection (China University of Geosciences, Beijing), Ministry of Education. We are deeply indebted to Prof. Weerachai Siripunvaraporn and two anonymous reviewers for their valuable comments and suggestions that improved the manuscript. The magnetotelluric data are from the previous INDEPTH projects and the Chinese Geological Survey. We used the 3D MT inversion code ModEM to obtain the electrical model, and we used the GMT software package to produce some of the figures.

\section{Competing interests}

The authors declare that they have no competing interests.

\section{Availability of data and materials}

The magnetotelluric data are from the INDEPTH projects and the Chinese Geological Survey. The time series and impedance data could not be shared because of the confidentiality agreement.

\section{Ethics approval and consent to participate}

Not applicable.

\section{Consent for publication}

Not applicable.

\section{Publisher's Note}

Springer Nature remains neutral with regard to jurisdictional claims in published maps and institutional affiliations.

Received: 2 May 2017 Accepted: 17 October 2017

Published online: 25 October 2017

\section{References}

Bai D, Unsworth MJ, Meju MA, Ma X, Teng J, Kong X, Sun Y, Sun J, Wang L, Jiang C, Zhao C, Xiao P, Liu M (2010) Crustal deformation of the eastern Tibetan plateau revealed by magnetotelluric imaging. Nat Geosci 3(5):358-362

Cai JT, Chen X-B (2010) Refined techniques for data processing and two-dimensional inversion in magnetotelluric II Which data polarization mode should be used in 2D inversion. Chin J Geophys Chin Ed 53(11):2703-2714

Chen LH, Booker JR, Jones AG, Wu N, Unsworth MJ, Wei WB, Tan HD (1996) Electrically conductive crust in southern Tibet from INDEPTH magnetotelluric surveying. Science 274(5293):1694-1696

Chen Y, Li W, Yuan X, Badal J, Teng J (2015) Tearing of the Indian lithospheric slab beneath southern Tibet revealed by SKS-wave splitting measurements. Earth Planet Sci Lett 413:13-24

Clark MK, Royden LH (2000) Topographic ooze: building the eastern margin of Tibet by lower crustal flow. Geology 28(8):703-706
Ding H, Zhang Z, Dong X, Tian Z, Xiang H, Mu H, Gou Z, Shui X, Li W, Mao L (2016a) Early Eocene (c. $50 \mathrm{Ma}$ ) collision of the Indian and Asian continents: constraints from the North Himalayan metamorphic rocks, southeastern Tibet. Earth Planet Sci Lett 435:64-73

Ding H, Zhang Z, Hu K, Dong X, Xiang H, Mu H (2016b) P-T-t-D paths of the North Himalayan metamorphic rocks: implications for the Himalayan orogeny. Tectonophysics 683:393-404

Egbert GD, Kelbert A (2012) Computational recipes for electromagnetic inverse problems. Geophys J Int 189(1):251-267

England P, Houseman G (1989) Extension during continental convergence, with application to the Tibetan plateau. J Geophys Res Solid Earth Planets 94(B12):17561-17579

Gao R, Xiong XS, Li QS, Lu ZW (2009) The Moho depth of Qinghai-Tibet plateau revealed by seismic detection. Acta Geosci Sin 30(6):761-773

Gao R, Chen C, Lu ZW, Brown LD, Xiong XS, Li WH, Deng G (2013) New constraints on crustal structure and Moho topography in Central Tibet revealed by SinoProbe deep seismic reflection profiling. Tectonophysics 606:160-170

Gao R, Lu Z, Klemperer SL, Wang H, Dong S, Li W, Li H (2016) Crustal-scale duplexing beneath the Yarlung Zangbo suture in the western Himalaya. Nat Geosci 9(7):555-560

Guilmette C, Hébert R, Dupuis C, Wang C, Li Z (2008) Metamorphic history and geodynamic significance of high-grade metabasites from the ophiolitic mélange beneath the Yarlung Zangbo ophiolites, Xigaze area, Tibet. J Asian Earth Sci 32(5-6):423-437

Hou Z, Zhang H, Pan X, Yang Z (2011) Porphyry Cu (-Mo-Au) deposits related to melting of thickened mafic lower crust: examples from the eastern Tethyan metallogenic domain. Ore Geol Rev 39(1-2):21-45

Hou Z-Q, Zheng Y-C, Zeng L-S, Gao L-E, Huang K-X, Li W, Li Q-Y, Fu Q, Liang W, Sun Q-Z (2012) Eocene-Oligocene granitoids in southern Tibet: constraints on crustal anatexis and tectonic evolution of the Himalayan orogen. Earth Planet Sci Lett 349-350:38-52

Hou Z, Yang Z, Lu Y, Kemp A, Zheng Y, Li Q, Tang J, Duan L (2015) A genetic linkage between subduction- and collision-related porphyry Cu deposits in continental collision zones. Geology 43(3):247-250

Hu X, Garzanti E, Moore T, Raffi I (2015) Direct stratigraphic dating of India-Asia collision onset at the Selandian (middle Paleocene, $59 \pm 1 \mathrm{Ma}$ ). Geology 43(10):859-862

Hu X, Garzanti E, Wang J, Huang W, An W, Webb A (2016) The timing of India-Asia collision onset-Facts, theories, controversies. Earth Sci Rev 160:264-299

Karplus MS, Zhao W, Klemperer SL, Wu Z, Mechie J, Shi D, Brown LD, Chen C (2011) Injection of Tibetan crust beneath the south Qaidam Basin: evidence from INDEPTH IV wide-angle seismic data. J Geophys Res 116(B7):86-94

Kelbert A, Meqbel N, Egbert GD, Tandon K (2014) ModEM: a modular system for inversion of electromagnetic geophysical data. Comput Geosci 66:40-53

Kind R, Yuan X, Saul J, Nelson D, Sobolev SV, Mechie J, Zhao W, Kosarev G, $\mathrm{Ni}$ J, Achauer U, Jiang M (2002) Seismic images of crust and upper mantle beneath Tibet: evidence for Eurasian plate subduction. Science 298(5596):1219-1221

Kosarev G, Kind R, Sobolev SV, Yuan X, Hanka W, Oreshin S (1999) Seismic evidence for a detached Indian lithospheric mantle beneath Tibet. Science 283(5406):1306-1309

Le Pape F, Jones AG, Vozar J, Wei WB (2012) Penetration of crustal melt beyond the Kunlun Fault into northern Tibet. Nat Geosci 5(5):330-335

Le Pape F, Jones AG, Unsworth MJ, Vozar J, Wei W, Jin S, Ye G, Jing J, Dong H, Zhang L, Xie C (2015) Constraints on the evolution of crustal flow beneath Northern Tibet. Geochem Geophys Geosyst 16(12):4237-4260

Ledo J, Queralt P, Marti A, Jones AG (2002) Two-dimensional interpretation of three-dimensional magnetotelluric data: an example of limitations and resolution. Geophys J Int 150(1):127-139

Li YL, Wang CS, Dai JG, Xu GQ, Hou YL, Li XH (2015) Propagation of the deformation and growth of the Tibetan-Himalayan orogen: a review. Earth Sci Rev 143:36-61

Liang X, Chen Y, Tian X, Chen YJ, Ni J, Gallegos A, Klemperer SL, Wang M, Xu T, Sun C, Si S, Lan H, Teng J (2016) 3D imaging of subducting and fragmenting Indian continental lithosphere beneath southern and central Tibet using body-wave finite-frequency tomography. Earth Planet Sci Lett 443:162-175 
Liu X, Hsu KJ, Ju Y, Li G, Liu X, Wei L, Zhou X, Zhang X (2012) New interpretation of tectonic model in south Tibet. J Asian Earth Sci 56:147-159

Ma X, Xu Z, Meert JG (2016) Eocene slab breakoff of Neotethys as suggested by dioritic dykes in the Gangdese magmatic belt, southern Tibet. Lithos 248-251:55-65

Mo X, Niu Y, Dong G, Zhao Z, Hou Z, Zhou S, Ke S (2008) Contribution of syncollisional felsic magmatism to continental crust growth: a case study of the Paleogene Linzizong volcanic succession in southern Tibet. Chem Geol 250(1-4):49-67

Nabelek PI, Nabelek JL (2014) Thermal characteristics of the Main Himalaya Thrust and the Indian lower crust with implications for crustal rheology and partial melting in the Himalaya orogen. Earth Planet Sci Lett 395:116-123

Nabelek J, Hetenyi G, Vergne J, Sapkota S, Kafle B, Jiang M, Su H, Chen J, Huang B-S, Hi CT (2009) Underplating in the Himalaya-Tibet collision zone revealed by the Hi-CLIMB experiment. Science 325(5946):1371-1374

Owens TJ, Zandt G (1997) Implications of crustal property variations for models of Tibetan plateau evolution. Nature 387(6628):37-43

Richard Styron MHT (2010) Database of active structures from the Indo-Asian Collision. EOS Trans Am Geophys Union 91:181-182

Rippe D, Unsworth M (2010) Quantifying crustal flow in Tibet with magnetotelluric data. Phys Earth Planet Inter 179(3-4):107-121

Rodi W, Mackie RL (2001) Nonlinear conjugate gradients algorithm for 2-D magnetotelluric inversion. Geophysics 66(1):174-187

Rosenberg CL, Handy MR (2005) Experimental deformation of partially melted granite revisited: implications for the continental crust. J Metamorph Geol 23(1):19-28

Streule MJ, Searle MP, Waters DJ, Horstwood MSA (2010) Metamorphism, melting, and channel flow in the Greater Himalayan Sequence and Makalu leucogranite: constraints from thermobarometry, metamorphic modeling, and U-Pb geochronology. Tectonics 29(5):633-650

Tapponnier P, Xu ZQ, Roger F, Meyer B, Arnaud N, Wittlinger G, Yang JS (2001) Geology - oblique stepwise rise and growth of the Tibet plateau. Science 294(5547):1671-1677

Tian X, Chen Y, Tseng T-L, Klemperer SL, Thybo H, Liu Z, Xu T, Liang X, Bai Z, Zhang X, Si S, Sun C, Lan H, Wang E, Teng J (2015) Weakly coupled lithospheric extension in southern Tibet. Earth Planet Sci Lett 430:171-177

Unsworth M, Wei WB, Jones AG, Li SH, Bedrosian P, Booker J, Sheng J, Deng M, Tan HD (2004) Crustal and upper mantle structure of northern Tibet imaged with magnetotelluric data. J Geophys Res Solid Earth 109:B02403

Unsworth MJ, Jones AG, Wei W, Marquis G, Gokarn SG, Spratt JE, Team I-M (2005) Crustal rheology of the Himalaya and southern Tibet inferred from magnetotelluric data. Nature 438(7064):78-81

Wang C, Dai J, Zhao X, Li Y, Graham SA, He D, Ran B, Meng J (2014) Outwardgrowth of the Tibetan plateau during the Cenozoic: a review. Tectonophysics 621:1-43

Wannamaker PE, Hohmann GW, Ward SH (1984) Magnetotelluric responses of 3-dimensional bodies in layered earths. Geophysics 49(9):1517-1533

Wei WB, Unsworth M, Jones A, Booker J, Tan HD, Nelson D, Chen LS, Li SH Solon K, Bedrosian P, Jin S, Deng M, Ledo J, Ray D, Roberts B (2001) Detection of widespread fluids in the Tibetan crust by magnetotelluric studies. Science 292(5517):716-718

Wei W, Jin S, Ye G, Deng M, Jing J, Unsworth M, Jones AG (2009) Conductivity structure and rheological property of lithosphere in southern Tibet inferred from super-broadband magnetotelluric sounding. Sci China Earth Sci 53(2):189-202

Wittlinger G, Farra V, Hetenyi G, Vergne J, Nabelek J (2009) Seismic velocities in southern Tibet lower crust: a receiver function approach for eclogite detection. Geophys J Int 177(3):1037-1049

Xie C, Jin S, Wei W, Ye G, Jing J, Zhang L, Dong H, Yin Y, Wang G, Xia R (2016) Crustal electrical structures and deep processes of the eastern Lhasa terrane in the south Tibetan plateau as revealed by magnetotelluric data. Tectonophysics 675:168-180

Xu Z, Ma X (2015) The Chinese Phanerozoic gneiss domes: subduction-related type, collision-related type and combination type of subduction-collision. Acta Petrol Sin 31:3509-3523
Xu Z, Yang J, Li W, Zeng L, Xu C (2012) Tectonic background of important metallogenic belts in the southern and southeastern Tibetan plateau and ore prospecting. Acta Geol Sin 86(12):1857-1868

Xu Z, Wang Q, Pêcher A, Liang F, Qi X, Cai Z, Li H, Zeng L, Cao H (2013) Orogenparallel ductile extension and extrusion of the Greater Himalaya in the late Oligocene and Miocene. Tectonics 32(2):191-215

Xu Q, Zhao JM, Yuan XH, Liu HB, Pei SP (2015a) Mapping crustal structure beneath southern Tibet: seismic evidence for continental crustal underthrusting. Gondwana Res 27(4):1487-1493

Xu ZQ, Dilek Y, Yang JS, Liang FH, Liu F, Ba DZ, Cai ZH, Li GW, Dong HW, Ji SC (2015b) Crustal structure of the Indus-Tsangpo suture zone and its ophiolites in southern Tibet. Gondwana Res 27(2):507-524

Yang J, Meng F, Xu X, Robinson PT, Dilek Y, Makeyev AB, Wirth R, Wiedenbeck M, Cliff J (2015) Diamonds, native elements and metal alloys from chromitites of the Ray-lz ophiolite of the Polar Urals. Gondwana Res 27(2):459-485

Yang Z, Hou Z, Chang Z, Li Q, Liu Y, Qu H, Sun M, Xu B (2016) Cospatial Eocene and Miocene granitoids from the Jiru Cu deposit in Tibet: petrogenesis and implications for the formation of collisional and postcollisional porphyry Cu systems in continental collision zones. Lithos 245:243-257

Yin A (2006) Cenozoic tectonic evolution of the Himalayan orogen as constrained by along-strike variation of structural geometry, exhumation history, and foreland sedimentation. Earth Sci Rev 76(1-2):1-131

Yin A, Harrison TM (2000) Geologic evolution of the Himalayan-Tibetan orogen. Annu Rev Earth Planet Sci 28:211-280

Zhang Z, Deng Y, Teng J, Wang C, Gao R, Chen Y, Fan W (2011) An overview of the crustal structure of the Tibetan plateau after 35 years of deep seismic soundings. J Asian Earth Sci 40(4):977-989

Zhang Z, Chen Y, Yuan X, Tian X, Klemperer SL, Xu T, Bai Z, Zhang H, Wu J, Teng $J$ (2013) Normal faulting from simple shear rifting in South Tibet, using evidence from passive seismic profiling across the Yadong-Gulu Rift. Tectonophysics 606:178-186

Zhang H, Zhao D, Zhao J, Liu H (2015) Tomographic imaging of the underthrusting Indian slab and mantle upwelling beneath central Tibet. Gondwana Res 28(1):121-132

Zhang H, Zhao J, Zhao D, Yu C, Liu H, Hu Z (2016) Complex deformation in western Tibet revealed by anisotropic tomography. Earth Planet Sci Lett 451:97-107

Zhao WJ, Nelson KD (1993) Deep seismic reflection evidence for continental underthrusting beneath southern Tibet. Nature 366(6455):557-559

Zhao Z, Mo X, Dilek Y, Niu Y, DePaolo DJ, Robinson P, Zhu D, Sun C, Dong G, Zhou S (2009) Geochemical and Sr-Nd-Pb-O isotopic compositions of the post-collisional ultrapotassic magmatism in SW Tibet: petrogenesis and implications for India intra-continental subduction beneath southern Tibet. Lithos 113(1-2):190-212

Zhao W, Kumar P, Mechie J, Kind R, Meissner R, Wu Z, Shi D, Su H, Xue G, Karplus M, Tilmann F (2011) Tibetan plate overriding the Asian plate in central and northern Tibet. Nat Geosci 4(12):870-873

Zhao JM, Murodov D, Huang Y, Sun YS, Pei SP, Liu HB, Zhang H, Fu YY, Wang W, Cheng HG, Tang W (2014a) Upper mantle deformation beneath central-southern Tibet revealed by shear wave splitting measurements. Tectonophysics 627:135-140

Zhao JM, Zhao DP, Zhang H, Liu HB, Huang Y, Cheng HG, Wang W (2014b) P-wave tomography and dynamics of the crust and upper mantle beneath western Tibet. Gondwana Res 25(4):1690-1699

Zhu D-C, Zhao Z-D, Niu Y, Mo X-X, Chung S-L, Hou Z-Q, Wang L-Q, Wu F-Y (2011) The Lhasa terrane: record of a microcontinent and its histories of drift and growth. Earth Planet Sci ers 301(1-2):241-255

Zhu D-C, Zhao Z-D, Niu Y, Dilek Y, Hou Z-Q, Mo X-X (2013) The origin and pre-Cenozoic evolution of the Tibetan plateau. Gondwana Res 23(4):1429-1454 